003.349.3

811.161.1'354"19"

https://doi.org/10.18485/sj.2018.23.1.16

ВАНА С. СТАНИШИЪ

Универзитет у Београду

Филолошки факултет
Оригинални научни рад

Примљен: 04. 01. 2018.

Прихваћен: 29. 01. 2018.

\title{
ОРТОГРАФИЈА И РЕВОЛУЦИЈА - СУДБИНА РУСКЕ ЋИРИЛИЦЕ У РЕФОРМАТОРСКИМ ПРОЈЕКТИМА XX BEKA
}

Тему овога рада представља симболичка улога писма (писмо као симбол припадности одређеном културном кругу), показана на примеру судбине руске ћирилице у наведеном периоду. Како би овде требало да буде показано, писмо и ортографија, као у огледалу, одражавају супротстављеност интегративних и дезинтегративних сила у руској култури и руском друштву током XX века.

Кључне речи: писмо, ортографија, реформе руске ћирилице.

Заједно с гашењем црквенословенскога језика код православних Словена почетком XVIII в., из употребе је изишла и црквена (полу)уставна ћирилица. У XVI-XVII веку, пак, пословним, курзивним типом ћирилице, и на свом народном језику, штампали су своје књиге католички словенски кругови у Босни и на јадранском приморју. Такав избор по питању језика и писма направио је и руски император Петар I. Идеолошки разлог за такав избор писма било је знаменито Петрово западњаштво, надахнутост католичко-протестантском културом Запада, која је кроз његову реформу постала космополитски модел за подражавање. За разлику од босанских фрањеваца, који су у својим књигама употребили народно писмо свога словенског становништва, ${ }^{1}$ Петрова ћири-

\footnotetext{
*vanjast61@gmail.com

${ }^{1}$ Чигоя, Станишич 2017.
} 
лица била је у основи не само курзивна (,скорописна”) него и „преоденута у немачку одећу", 2 тј. преобликована по угледу на латинску антикву - као графијски израз нове, грађанске Русије, чији је званични језик постао 'живи' (народни) руски језик.

Као што је то већ разјаснио В. М. Живов, подела алфабета на црквени и грађански доносила је читаву схему супротности у руској култури. За опозицијом на графичком плану требало је да следи супротстављање осталих језичких одлика, тако да је реформа азбуке схематски садржала све основне моменте петровске језичке политике. ${ }^{3}$ У том смислу, традиционална култура била је доживљена као заостало и клерикално културно наслеђе и потиснута на периферију заједно са старим типом писма. „Клерикалним” словима била су у првом реду проглашена она слова која су означавала грчко графијско наслеђе. Графијско јединство с грчким било је жигосано као ником више потребно „гречествование по славенски”4, у првом реду правила писања 多 а не кс

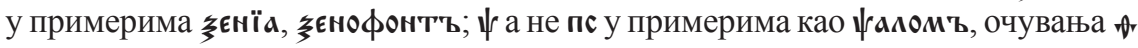
уместо ф у таквим речима као нєедшръ а не фєодшръ (зато што прва, како је то разјашњавао Ф. Поликарпов, означава вгодАръ , а друга $\mathbf{s м ~ і ̈ о д а р ъ ) , ~ ч у в а њ а ~}$ v ради оригиналног писања мартүрїн, тргфшнъ (Живов 1996: 78-79).

С друге стране, грађански тип писма, у основи којег се налазило „российское гражданское наречие", постао је симбол петровске секуларне просвећености - нове империјске културе. За његову графијску форму Петар I је изабрао латинску антикву с додацима из рускога скорописа, прерађеним по угледу на латиницу, ${ }^{5}$ тамо где није могло све да се реши само латиничким словима (нпр. $\sigma, 2, ж, л, н)$, док је произвољно, по спољашњој сличности, узео латиничке $\mathrm{g}, \mathrm{n}, \mathrm{m}$ за облик малих ћириличких $\partial, n, m$. У складу с тим, он је искључио све дублетне знаке у корист латиноидних варијанти: $\mathbf{n , ~ v / l , ~}$

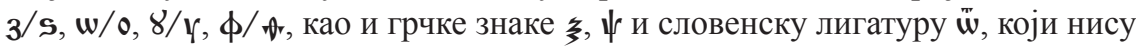
одговарали фонетском принципу. ${ }^{6}$ Прва фаза грађанског типа писма из 1708. године показала се толико радикалном и пренагљено латиноидном, да се сам император касније одрекао знатног броја својих решења и у коначној верзији вратио првобитно избачене н, 3, 8, $\phi, \mathbf{v}, \xi$. Коначно одстрањени остали су само $\boldsymbol{w}, \boldsymbol{w}, \downarrow$. Различита судбина грчких слова $\xi$ и $中$ представља одступање од постулиране радикалне фонетизације и обично се објашњава потребом

${ }^{2}$ Якубовский 2009: 391.

${ }^{3}$ Живов 1996: 73.

${ }^{4}$ Како се изразио В. К. Тредиаковски у своме раду Разговор между чужестранным человеком і Россійскім об ортографіi старінной і новой і о всем что прінадлежіт к сей матеріі. СПб. 1748, 44; Живов 1996: 79.

${ }^{5}$ Ефимов 1994.

${ }^{6}$ Шицгал: 37-41. 
да се напише његово име по оцу Але потом „исправљен” коначним уклањањем слова 多 од стране Академије наука 1735. Очигледно, у таквом запису његово је име по оцу („отчество”) чувало нежељену везу с грчким, без обзира на то што се враћање тога слова може објаснити такође оријентацијом на латиницу - одстрањена су углавном била она слова која нису имала подршку у латиничкој писмености. Зато су и академски кругови дали предност постепеном остварењу радикално фонетске форме руског писма, назначене у првој фази петровске реформе.

Петрова реформа охрабрила је прозападне кругове за коначан прелазак на латиницу, како је то још 1748. г. изразио В. К. Тредиаковски: „Нова руска азбука мора, што је могуће више, да својим изгледом личи на латинско, а не на грчко писмо, будући да је управо ради тог циља она и била саздана и уведена у употребу од стране Петра I". ${ }^{8}$ Средином XIX в. ове идеје претварају се у латиничке пројекте, међу којима се издваја Uproszenie ruscoi grammatichi К. М. Кадинскога (Кодинскога), о којем се похвално изјаснио знаменити књижевни критичар В. Г. Белински, који је на основи тога рада предлагао своју варијанту руске латинице. ${ }^{9}$ Природна прелазна фаза у овом правцу била је фонетизација руске ортографије. Инсистирање на што је могуће тачнијем подударању између знакова руског писма и гласова руског језика, и величање идеала фонетске ортографије, било је водећи принцип практично свих потоњих ортографских реформи и пројеката у руској писмености. Стање духа у руској култури друге половине XVIII ст. илуструје спис М. В. Ломоносова Судъ Россійскихъ письменъ передъ разумомъ и обычаемъ оть грамматики представленныхъ (Лъкарство отъ скуки и заботъ. N 46. Середа. Маія 12 дня 1787 года), у којем је он с подсмехом иронизирао над неподударностима словног састава руског писма, изрекавши чувену осуду о слову ъ „НЂмой мъсто занялъ. Подобіе какъ пятое колесо", која је потом постала својеврсна крилатица реформе ћириличке ортографије. ${ }^{10}$

Иако пројекти фонетизације, за разлику од латиничких пројеката, нису дирали форму руског писма и чак су пропагирали његову националну оригиналност, у оба случаја то је било супротстављање националног писма националној традицији. У својим најрадикалнијим облицима то је био удар на руско историјско наслеђе у целини. Упор. нпр. ватрену западњачку изјаву

\footnotetext{
${ }^{7}$ Григирьева, Осипов 2009: 15.

${ }^{8}$ В.К. Тредиаковский, Разговор между чужестранным человеком і Россійскім об ортографіі старінной і новой і о всем что прінадлежіт к сей матеріi. СПб., 1748; Narloch 2014: $41-42$.

${ }^{9}$ Narloch 2014: 44-45.

${ }^{10}$ При чему не само у руској писмености: управо с обрачуном с овим „петим точком” ћириличке азбуке започеће реформа ћирилице у Срба. Упор. Станишић 1987: 26; Окука 2010; Милановић 2013.
} 
већ поменутог латинисте К. М. Кадинскога о томе да „латинско писмо има неоспорно преимућство у односу на наше: оно је чишће, лепше, читљивије и заузима мање места, (...) а наша варварска азбука придаје нам непријатни, скитски тон, који квари сјај наше образованости". ${ }^{11}$ Како је показала Алесја Нарлох, такве радикалне западњачке идеје и пројекти изазвали су одговор словенофилских кругова у виду покушаја заштите старе ортографије и чак пропагирања саме ћирилице као пансловенског писма. Борба између тих двеју непомирљивих позиција, као што је познато, окончала се скоро потпуном победом пројеката фонетизације руске ортографије, а у различитим облицима она се водила током читавог XX столећа. Противницима фонетизације засад је пошло за руком само да привремено зауставе такав процес.

Реформа руског правописа 1917. године, која је обликовала садашњи изглед рускога писма, прославила се тиме што је укинула графичко-ортографску норму на којој су била написана сва дела тзв. Златног века руске књижевности. Реформа се обично назива укидањем старе ортографије или упрошћавањем руског правописа, а испољила се у потпуном одстрањењу свих оних знакова који нису имали гласовну функцију. Од старе ортографије остала су само слова која имају везе с гласовном страном језика. Општа одлика одстрањених слова било је чување различитих културно-историјских и филолошких садржаја. У првом реду, та слова су чувала успомену на руску културну историју: међу њима v „ижица” и ө „фита” (одстрањене у корист сазвучних $u, \phi)$ биле су не само маркери црквене лексике, већ и графички одраз грчко-словенског света - Pax Slavia Orthodoxa, како се он данас назива захваљујући италијанском слависти Рикарду Пикију. Слова i „и десетерично” и ‘ ,jaт” (одстрањена у корист сазвучних и, е) имала су такав граматичко-филолошки значај, да их је немогуће било одстранити без озбиљних културних губитака и штете. Најбоље је прошао већ поменути знак ъ, за који се испоставило да није баш такав „пети точак" - упркос покушајима његовог потпуног укидања, он се показао као најбољи маркер тврдога изговора сугласника у средини речи.

Као што је познато, таква ортографска реформа настала је у времену државне кризе и револуционарних догађања која су била искоришћена у циљу опустошења и разарања друштвеног поретка чији је графички симбол представљала стара ортографија. И колико год то чудно било, разрађена је била управо од стране Ортографске поткомисије Академије наука, под руководством знаменитог филолога А. А. Шахматова уочи Прве револуције 1905. године и у коначном виду објављена у форми резолуције 1912. године. Али је за спровођење реформе био потребан државни преврат, а једно од првих решења Привремене владе било је „Постановление совещания по вопросу об упрощении русского правописания" (11. маја 1917). Само недељу дана

${ }^{11}$ Narloch 2014: 46. 
после тога, 17. маја, Министарство народне просвете наложило је да се одмах спроведе реформа рускога правописа. Смена власти није се ни у чему одразила на „питање руског правописа” - бољшевици су укинули већину наредби Привремене владе - осим ове. ${ }^{12}$

У совјетском раздобљу је ова ортографска реформа, проглашена од стране Привремене владе, тесно поистовећена с њеним идеолошким непријатељима - бољшевицима, а заштита старог начина писања с обележјем контрареволуционарности. ${ }^{13}$ Управо је из таквог разлога издржао у младости петогодишњу робију потоњи руски академик Д. С. Лихачов, осуђен за свој рад о старој ортографији, који је био прочитан у студентском кружоку 1928. године - у јеку припремане латинизације читаве земље од стране совјетске власти. Без обзира на млади узраст, велики научник је у томе раду, с којег је забрана била скинута тек почетком 90-их година, разобличио псеудонаучне аргументе и оправдања у корист фонетизације руског правописа, које су присталице реформе понављали током читавог XX столећа. Тези о ослобођењу руског писма од сувишних, мртвих слова, графичког баласта и архаичних, застарелих форми, ${ }^{14}$ млади Лихачов је супротставио следећи аргумент: комуникативну улогу нефонетских знакова - ,фонетски сувишни знаци нису такви и графички”. ${ }^{15}$ Као што усмени говор има на располагању интонацију, тако је и писмени говор „принуђен да прибегава таквим ознакама каквих нема у живом говору” <..> „зато што ми не читамо по словима или слоговима, како то чине малописмени људи, већ обухватамо читаву реч по њеној физиономији".

Даља је критика разоткрила размере штете изазване ишчезавањем културних и цивилазацијских садржаја, као последице ортографске реформе 1917. године. Како је показао знаменити философ И. А. Иљин, „Од тога је пострадала и страда сва руска култура... Сви проблеми міра (света), мірозданія (свемира), міровоззрънія (светоназора); микрокосма, макрокосма; знанія и въдънія и многих других, с њима повезаних садржаја, обесмишљени су и пропали. Ни једног философа више није могуће писмено превести на руски језик... Постали су бесмислени сви стихови који певају о свету и свемиру ( о мірғ и мірозданіи); немогуће их је све побројати... Ајвазовски је назвао своју слику „На морє” (гдъ?); из тога је настало „На море” (куда?)”. ${ }^{16}$ На тај су се начин, по речима Филипа Амона, слиле супротности нвкогда (некада) и некогда (нема времена). Затрла се графичка разлика међу првніемъ (труљењем) и преніемъ (спором). „Смисао совјетске крилатице „міру миръ” (наслеђене из богослужбеног „мира

\footnotetext{
${ }^{12}$ Александров-Деркаченко 2016.

${ }^{13}$ Малахов 2003.

${ }^{14}$ Григорьева 2004: 8; Григорьева 2017; Карпова 2010.

${ }^{15}$ Лихачев 1993: 46.

${ }^{16}$ Ильинъ 1956.
} 
мірови у Господа просимъ”) замаглио се реформом". ${ }^{17}$ Затрла се разлика међу миромъ, міромъ и мvромъ (,Затворио се Мебиусов круг”).

Теза о универзалној супериорности фонетске ортографије, која може игнорисати социокултурна питања, временом је разобличена у социолингвистици. Њену макиавелистичку примену разоткрио је Valter Tauli, који је 1968. године, пропагирајући супериорност фонетске ортографије, изјавио: „, if social, political, psychological, typographical and economic conditions happened to be in conflict with it, it was the duty of the linguist simply to insist that the orthography they were providing was better". ${ }^{18}$ Ово се управо испољило у ортографским пројектима и дискусијама совјетског периода. Таква су нпр. била величања принципа економије при упрошћавању ортографије и тврдње о „лажној научности" етимолошке (историјске) ортографије од стране идеолога реформе 1904. године, ${ }^{19}$ што је често понављано током каснијих реформаторских корака: нпр. изјаве о „економској користи при критичном дефициту хартије”, „ради олакшања широким масама усвајања руске писмености и ослобођења школе од непроизводног рада при учењу правописа", приликом спровођења реформе 1917. године. ${ }^{20}$ Већ 1929. године Главнаука (тада главни државни орган за координацију и пропаганду науке и културе) саопштава како и тако упрошћена ћирилица ,jеде” много хартије и да је полиграфска индустрија израчунала да може остварити огромну економску корист од латинизације руског писма, док је аутор саме латинизације - познати лингвист Н. Ф. Јаковљев, територију коју руски језик заузима у границама Совјетског Савеза назвао „прежитком русификаторске политике царских мисионара", а територију руског алфабета својеврсним клином, забијеним међу земљама где је прихваћен латинички алфабет, услед чега руски алфабет представља „безусловни анахронизам” који треба ликвидирати. ${ }^{21}$

Напред речено потврђује речи Марка Себе, исказане у уводном делу зборника радова посвећеном социјалним одликама писма и ортографије, које носе основну поруку читаве књиге: „If proof were needed, the foregoing should be sufficient to destroy the idea that writing systems and orthographies are socially neutral technologies". ${ }^{22}$ На совјетском примеру ово је још 1989. разјаснио Марк Дикенс (Dickens 1989), показавши да су совјетску језичку политику у централној Азији одређивале ,inherent tensions between centripetal and centrifugal forces

\footnotetext{
${ }^{17}$ Аммонъ 2016: 251-253.

18 „Ако би друштвени, политички, психолошки, типографски и економски услови дошли с тим у сукоб [с тезом о супериорности фонетске ортографије], дужност би лингвиста била само да инсистирају на томе да је ортографија коју су они предлагали боља"(Sebba 2012: 2).

${ }^{19}$ Леонова 2006; Леонова 2007: 16.

${ }^{20}$ Малахов 2003.

${ }^{21}$ Алпатов 2015

22 „Ако би доказ био потребан, оно што следи требало би да буде довољно да покопа тезу како су писмени системи и ортографије друштвено неутралне технологије” (Mark Sebba 2012: 9).
} 
in the Soviet multicultural society" (,унутрашње тензије између центрипеталних и центрифугалних сила у совјетском мултикултурном друштву”). Већ од првих година своје владавине совјетска власт почела је да спроводи свеопшту латинизацију земље, зато што је, по речима А. В. Луначарског, „била свесна тога” да је у реформисаној ортографији „по самој половичности својој, било нешто 'фебруарско', а не октобарско". ${ }^{23}$ Латинизација се испољила у потпуном укидању арапског писма у централној Азији и покушају укидања ћирилице као „безусловних анахронизама”. Схвативши како је поменути пројекат "politically suicidal", ${ }^{24}$ власт је 30-их година спровела, за многе неочекиван, одлучан заокрет према центрипеталном (интегративном) правцу развоја - сменом „,ееинске” латинице ћирилицом. После крупних промена у врху власти, почетком 60-их година дискусија о даљој реформи руске ортографије обнавља се тоном и реториком који подсећају на аргументацију 20-их година. Отпочело се тврдњама како је реформа 1918-1930. г. била „заустављена реакционарном професуром”, како је руска ортографија „постала главна препрека у процесу учења", како ће упрошћавање ортографије омогућити да се увећа време на изучавање самог језика и како се могу жртвовати историјски облици писања, да би се ортографија довела у склад с језиком („Правопис није историјски музеј”, по речима А. И. Јефимова). ${ }^{25}$ Како је то јасно показала Е. В. Арутјунова, реформа је очигледно проистицала од највиших органа власти и питање упрошћавања ортографије било је већ решено на државном нивоу. Сасвим је очигледан наручени карактер првих публикација о реформи. Требало је да се створи утисак о постојању друштвене потребе. ${ }^{26}$ Међутим, таква је била и судбина саме реформе - ујутро 16. октобра 1964. било је објављено о изненадним крупним променама у врху власти, а већ те вечери појавио се разорни чланак против реформе, који је требало да послужи као сигнал од „виших инстанци” да је реформа обустављена, барем за сада (Арутюнова 2015: 173).

Изгубивши, очевидно, политичку подршку, крајем XX и почетком XXI столећа брзо се утишао покушај обнављања реформе ортографије све до преласка на латиницу, пошто се у постсовјетско доба руска ћирилица опет претворила у ,јаковљевски” клин који заостаје од „цивилизацијских потреба светских процеса глобализације". ${ }^{27}$ Али су засад били безуспешни и покушаји да се обнови (рехабилитује) стара ортографија - врате „репресирана слова” (по речима А. Вознесенског). ${ }^{28}$ Стара ортографија засад има само украсносимболичку улогу - среће се само у рекламама, етикетама, или називима неких

\footnotetext{
${ }^{23}$ Луначарский 1930.

${ }^{24}$ Dickens 1989.

${ }^{25}$ Арутюнова 2015: 20-22, 48.

${ }^{26}$ Арутюнова 2015: 102, 146; Арутюнова 2016: 6-7.

${ }^{27}$ Арутюнова 2015: 185-207; Алпатов 2015.

${ }^{28}$ Огонек 1987, № 12 (Григорьева 2017).
} 
компанија. Њена текстуална примена ограничена је само на неке часописе ултра-десног садржаја (какав је нпр. национално-патриотски фронт Память), што се одразило на индиферентан однос ширих слојева друштва па чак и цркве према питању обнове старе ортографије. ${ }^{29}$

Још један убедљив доказ да се писмо и ортографија не могу просто свести на визуелни говор, пружа рад Suzanne Wertheim, посвећен питању татарске писмености, који почиње следећим речима: „Alphabet changes are never purely linguistic in nature". ${ }^{30}$ Више од тога, у њеном је раду јасно показано да писмо и ортографија представљају метонимијска обележја политичке и културне оријентације - писмо обезбеђује метафоричку везу с обликом и начином живота, који се асоцирају с одређеним светом. У датом случају покушај да се крајем XX столећа врати латинички алфабет „саn be seen as symbolic gestures that index anti-Russian and pro-Western stances" ${ }^{11}$. Писмо и ортографија на тај начин служе као симболичка материјализација објеката којима се може манипулисати. Ону симболичку улогу какву стара ћириличка ортографија има у руској средини, у Татарстану имају туркијске руне и арапско писмо (или њима формално слични савремени типови писма). Они представљају симболичке сигнале различитих легитимности: старине, аутохтоности, исламске културе. У том смислу, веома је поучан пример симболичке улоге арапског писма, које функционише као „орроsitional identity” (Wertheim: 97). У савременом Татарстану њега скоро нико више не уме да чита, а за арапски свет оно је неразумљиво, зато што по језику и унутрашњој структури оно и није арапско. То је још један доказ симболичке улоге писма, која је важнија од његове везе с језиком. Зато је истицање језичког аргумента увек било повезано с ударом на писмо.

Судбина руске ћирилице у поменутим ортографским пројектима одражава, као у огледалу, супротстављеност интегративних и дезинтегративних сила у руској култури и руском друштву током XX века. То је конкретна илустрација прворазредне симболичке улоге писма као спољашњег, визуелног израза идентификације с одређеном цивилизацијом.

\footnotetext{
${ }^{29}$ Bennett 2012: 50-51.

${ }^{30}$ Wertheim 2012: 65.

${ }^{31}$ „Могу бити схваћени као симболички гестови који одражавају антируске и прозападне ставове" (Wertheim 2012: 91).
} 


\section{БИБЛИОГРАФИЈА}

Александров-Деркаченко 2016: П. П. Александров-Деркаченко, Великая орфографическая революция_РИСИ.htm. 25.04.2016. () 1992-2017, Российский институт стратегических исследований.

Алпатов 2015: В. М. Алпатов, „Русская латиница Н. Ф. Яковлева”, Научный диалог, № 3 (39), 2015, 8-28.

Аммонъ 2016: Ф. Аммонъ (Philipp Ammon): „Tractatus slavonicus”, Sjani (Thoughts) Georgian Scientific Journal of Literary Theory and Comparative Literature, N 17, 2016, 248-256.

Арутюнова 2015: Е. В. Арутюнова, Реформы русской орфографии и пунктуации в советское время и постсофетский период: лингвистические и социальные аспекты. Диссертация на соискание ученой степени кандидата филологических наук, РГГУ, Москва 2015.

Арутюнова 2016: Е. В. Арутюнова, „Реформа русской орфографии и пунктуации 1960-х годов: неизвестные страницы истории", Сибирский филологический журнал, № 3, 2016, 5-16.

Григорьева 2004: Т. М. Григорьева, Три века русской орфографии (XVII-XX вв.). Москва: Элиис, 2004.

Григорьева 2017: Т. М. Григорьева, „Реформа русской орфографии: от 'книжной искусственности к живой простоте'”, Русский язык в школе. 2017. № 3, 67-70.

Григорьева, Осипов 2009: Григорьева Т. М., Осипов Б. И., „От старой азбуки до современного алфавита", Кириллица, латиница, гражданица. Коллективная монография (отв. ред. Шмелева Т. В.), Новгород 2009. Министерство образования и науки Российской Федерации; „ИНОЦЕНТР (Информация. Наука. Образование)” Институт имени Кеннана Центра Вудро Вильсона (США), 11-19.

Ефимов 1994: В. Ефимов, „Драматическая история кириллицы. Великий петровский перелом”, Журнал „Да!”, № 0, Москва 1994.

Живов 1996: В. М. Живов, Язык и куьтура в России XVIII века, Москва: „Языки русской культуры”.

Ильинъ 1956: И. А. Ильинъ, „О русскомъ націиональномъ правописаніи”, (Наши задачи, т. II, Париж 1956), Русскій порталъ. Историческая библіотека русской цивилизаціи (http://www.russportal.ru/index. php?id=oldorth.iljin). 
Карпова 2010: О. Карпова, „История с орфографией. Неудавшиеся реформы русского правописания второй половины XX века”, Журнальный клуб Интелрос. Интелектуальная Россия, № 3, 2010.

Леонова 2006: Ж. В. Леонова, „Приципы орфографической нормализации в лингвистичских дискуссиях 1904 года”, Вестник Красноярского государственного педагогического университета им. В.П. Астафьева, 2006.

Леонова 2007: Ж. В. Леонова, „Фонетико-этимологический идеал Р. Ф. Брандта", Вестник новгородского государственного университета, № 43, 2007, 15-17.

Лихачев 1993: Д. С. Лихачев, „Любителям российской словесности”, Русская речь 1, 1993, 43-51 (Доклад Д. С. Лихачева [1928 г] о старой орфографии с предисловием В. П. Нерознака).

Луначарский 1930: А. В. Луначарский, „Латинизация русской письменности”, Культура и письменность востока, кн. VI, 1930, 20-26 [http:// lunacharsky.newgod.su/lib/raznoe/latinizacia-russkoj-pismennosti]

Малахов 2003: А. Малахов, „100 лет сплошного буквоедства”, Журнал „Коммерсанть Деньги” № 40 от 13.10.2003, стр. 115.

Милановић 2013: А. Милановић, Језик весма полезан [І. Развој ћирилице код Срба крајем 18. и у 19. веку, 21-79], „Књижевност и језик”, књ. 45, Београд 2013.

Окука 2010: М. Окука, „Сало дебелога јера либо азбукопротрес” Саве Мркаља у старом и новом руху, „Просвјета”, Загреб 2010.

Станишић 1987: В. Станишић, „Корени и домети Вукове реформе српске ћирилице", Повеља 1-2, Краљево 1987, 24-45.

Чигоя, Станишич 2017: Б. Чигоя, В. Станишич, „Несколько замечаний о кириллической письменности боснийских францисканских писателей XVII века", Коммуникология 2017, Том 5, № 1, 31-49.

Шицгал 1974: А. Г. Шицгал, Русский типографский шрифт, „Книга”.

Якубовский 2009: Э. А. Якубовский, „Петровская реформа кириллического письма", Культурное наследие России и перспективы мирового соииокультурного развития. Материалы Всероссийской научнопрактической конференции, Екатеринбург, 27-29 февраля 2008 г. Часть II, Екатеринбург 2009, 391-398. 
Bennett 2012: B. Bennett, "Orthography and Orthodoxy in post-Soviet Russia" (43-64), Orthography as social action. Scripts, spelling, identity and power (Eds. A. Jaffe, J. Androutsopoulos, M. Sebba, S. Johnson. De Gruiter Mouton, Berlin, Göttingen 2012.

Dickens 1989: M. Dickens, Soviet Language Policy in Central Asia, http://www. oxuscom.com/lang-policy.htm\#intro.

Narloch 2014: A. Narloch, „О латинизации русского письма в XVIII-XIX вв.”, Studia Rossica Gedanensia, 1/2014, 38-50.

Sebba 2012: M. Sebba, "Chapter 1. Orthography as social action: Scripts, spelling, identity and power" (1-19). Orthography as social action. Scripts, spelling, identity and power (Eds. A. Jaffe, J. Androutsopoulos, M. Sebba, S. Johnson. De Gruiter Mouton, Berlin, Göttingen 2012.

Wertheim 2012: S. Wertheim, "Reclamation, revalorization and re-Tatarization via changing Tatar orthographies" (65-101). Orthography as social action. Scripts, spelling, identity and power (Eds. A. Jaffe, J. Androutsopoulos, M. Sebba, S. Johnson. De Gruiter Mouton, Berlin, Göttingen 2012.

\section{ОРФОГРАФИЯ И РЕВОЛЮЦИЯ - СУДЬБА РУССКОЙ КИРИЛЛИЦЫ В ОРФОГРАФИЧЕСКИХ ПРОЕКТАХ ХХ СТОЛЕТИЯ}

\section{Резюмэ}

Темой данной статьи является символическая роль письма (письмо как символ принадлежности определенному культурному кругу), которая показана на примере судьбы русской кириллицы в XX столетии. Как здесь показано, письмо и орфография представляют собой зеркальное отражение противопоставления центробежных и центростремительных сил в русской культуре и российском обществе.

Ваня Станииич 